\title{
SEROPREVALENCE OF HSV, HBSAg \& HCV IN STD CLINIC ATTENDEES OF A TERTIARY CARE STATE HEADQUARTERS HOSPITAL
}

\author{
Venkata Ramana Godha, Prasad J. V. D. S2, Veena Kumari³, Padmaja Pinjala ${ }^{4}$, Venkata Krishna Ananthula 5 , \\ Subhash Reddy Dudhipala ${ }^{6}$, Prasad K. N7, Raghu Kiran ${ }^{8}$
}

\begin{abstract}
1 Professor, Department of Dermatology, Osmania Medical College \& Osmania General Hospital, Hyderabad, Telangana. ${ }^{2}$ Associate Professor, Department of Dermatology, Osmania Medical College \& Osmania General Hospital, Hyderabad, Telangana. ${ }^{3}$ Civil Assistant Surgeon, Department of Dermatology, Osmania Medical College \& Osmania General Hospital, Hyderabad, Telangana. ${ }^{4}$ Associate Professor, Department of Dermatology, Osmania Medical College \& Osmania General Hospital, Hyderabad, Telangana. ${ }^{5}$ Associate Professor, Department of Dermatology, Osmania Medical College \& Osmania General Hospital, Hyderabad, Telangana. ${ }^{6}$ Assistant Professor, Department of Dermatology, Osmania Medical College \& Osmania General Hospital, Hyderabad, Telangana. ${ }^{7}$ Assistant Professor, Department of Dermatology, Osmania Medical College \& Osmania General Hospital, Hyderabad, Telangana. ${ }^{8}$ Assistant Professor, Department of Dermatology, Osmania Medical College \& Osmania General Hospital, Hyderabad, Telangana.
\end{abstract}

\section{ABSTRACT}

\section{BACKGROUND}

Sexual activity in humans is meant for both procreative and recreational purposes. However, with the discovery of HIV/AIDS in 1981, concerns developed worldwide over unprotected sex. The unprotected sexual activity is contributing for transmission of symptomatic and asymptomatic STIs such as HIV, HBsAg and HCV.

The aim is to study seroprevalence of HBsAg, HSV \& anti-HCV antibodies in STD clinic attendees of Osmania Medical College/ Osmania General Hospital, Hyderabad.

\section{MATERIALS AND METHODS}

It is a descriptive study (observational study) conducted from January 2015 - December 2015 at STD Clinic OPD. A total of 3,583 patients who attended the STD Clinic during the above period were studied and patients having direct or indirect risk factors were serotested for the 3 viral infections after inclusion and exclusion criteria with informed consent. A 5 mL of venous blood is collected and the separated serum is tested for HSV 1\&2, HBsAg and Anti-HCV antibodies by using ELISA kits. It is ensured that the test kits used have $>95 \%$ sensitivity and specificity.

Settings \& Design- All eligible patients attending STD Clinic, Dept. of DVL, Osmania Medical College/Osmania General Hospital, Hyderabad were included in the study after inclusion and exclusion criteria with informed consent. A consecutive sampling methodology with zero intervals is followed. A percentage analysis method is used to derive the conclusions.

\section{RESULTS}

A total of 473 cases are found to be seropositives out of the 3,583 STD clinic attendees for either of 3 STIs showing a seroprevalence of $13.20 \%$, in which male seroprevalence is $13.56 \%$ (258 cases) and female seroprevalence is $12.80 \%$ ( 215 cases). In the studied population of 3583, 412 cases were seropositives for HSV Antibodies with seroprevalence of $11.5 \%, 39$ were HBsAg Antibodies positive with seroprevalence of $1.09 \%$ and 22 cases were positive for HCV antibodies with seroprevalence of $0.61 \%$. The seropositivity in males and females respectively for HSV is $11.56 \%$ and $11.43 \%$; for $\mathrm{HBsAg}$ is $1.26 \%$ and $0.89 \%$; for $\mathrm{HCV}$ is $0.74 \%$ and $0.48 \%$. The illiterates (376 of $473=79.49 \%$ ) and people of low socioeconomic status (371 of $473=78 \%$ ) are more affected. While 234 of 258 men are having either Premarital, Extramarital or combination accounting to $90.70 \%, 176$ of 215 (81.86\%) women are confined to marital sex.

\section{CONCLUSION}

The awareness on STIs needs to be well informed before the start of the sexual activity by incorporating the STI/RTI education in school and college curriculum, through IEC activities like mass media campaigns, print \& electronic media, by using local cultural festivals, gatherings and through marriage institutions. The at-risk populations such as Sex workers, MSM \& IDUs should be covered through specific targeted interventions by utilising NGOs, local bodies and associations.

\section{KEYWORDS}

Herpes Simplex Virus Type 1, Herpes Simplex Virus Type 2, Hepatitis B Virus, HSV 1, HSV 2, Anti-HCV Antibodies, Sexually Transmitted Viral Infections, STD Clinic, STD Clinic Attendees.

HOW TO CITE THIS ARTICLE: Godha VR, Prasad JVDS, Kumari V, et al. Seroprevalence of HSV, HBsAg \& HCV in STD clinic attendees of a tertiary care state headquarters hospital. J. Evolution Med. Dent. Sci. 2017;6(63):4609-4614, DOI: $10.14260 /$ Jemds/2017/997

Financial or Other, Competing Interest: None.

Submission 30-06-2017, Peer Review 25-07-2017,

Acceptance 31-07-2017, Published 07-08-2017.

Corresponding Author:

Dr. Prasad J. V. D. S

Associate Professor of STD/DVL,

Department of DVL (OP. No. 222),

$1^{\text {st }}$ Floor, OP Block, Osmania General Hospital,

Afzal Gunj, Hyderabad-500013, Telangana.

E-mail:drjvdsp@gmail.com

DOI: $10.14260 /$ jemds/2017/997

\section{BACKGROUND}

The Sexually Transmitted Diseases/Infections are caused by bacteria, virus, fungus and ectoparasites. The National AIDS Control Organisation (NACO), Government of India estimates that, the STI/RTI prevalence in the reproductive population is about $6 \% .^{1}$ Of late, it is reported that, the viral STIs are increasing in numbers. The transmission risk of HIV is increased by 4-10 times in the presence of other STIs/RTIs.

Five hepatitis viruses (hepatitis A to E) are the leading causes of liver disease worldwide. Among them, hepatitis B virus (HBV) is responsible for approximately 350 million 
chronic infections worldwide and over one million annual deaths, mostly as a result of end-stage liver disease and liver cancer. $^{2}$

At the present time, viral hepatitis is a major health problem worldwide, particularly in Asian countries. Hepatitis is caused by different hepatic viruses and it leads to chronic liver disease and leads to increased morbidity and mortality.

\section{Hepatitis B Virus (HBV)}

The hepatitis B virus (HBV) is noncytopathic, hepatotropic members of the hepadnavirus (HBV) families that cause acute and chronic necroinflammatory liver disease and hepatocellular carcinoma (HCC). ${ }^{3}$ It is associated with viral hepatitis B and its presence in body fluids like semen, vaginal secretions and saliva, demonstrates its transmission not only via blood but also by sexual contact.

\section{Hepatitis C Virus (HCV)}

HCV is a single-stranded RNA, enveloped virus that belongs to Flaviviridae family. Globally, an estimated 71 million people have chronic hepatitis $\mathrm{C}$ infection. A significant number of those who are chronically infected will develop cirrhosis or liver cancer. Approximately, 399000 people die each year from hepatitis $\mathrm{C}$, mostly from cirrhosis and hepatocellular carcinoma. ${ }^{4}$

HBV along with the hepatitis C virus (HCV) can cause broad-spectrum diseases such as hepatitis, fibrosis, cirrhosis and hepatocellular carcinoma (HCC) in the setting of chronic infection. ${ }^{2}$ The predominant modes of transmission are by blood, blood products, injecting drugs and sexual transmission in high-risk populations. ${ }^{5}$

\section{Herpes Simplex Virus 1 \& 2}

Herpes simplex viruses (HSVs) are DNA viruses that cause acute skin infections and present as grouped vesicles on an erythematous base. Most infections are recurrent and tend to reappear at or near the same location. Herpes labialis is the most common infection caused by HSV type 1 (HSV-1), whereas genital herpes is usually caused by HSV type 2 . The prevalence of HSV-1 infection has been found to be higher than that of HSV-2 infection in most geographic areas. ${ }^{6}$

In this scenario, the present study was undertaken to estimate the seroprevalence of Herpes Simplex Virus (HSV), HbsAg \& Anti-HCV antibodies infections in patients attending STD clinic OPD, Dept. of DVL, Osmania Medical College/Osmania General Hospital, Hyderabad from January 2015 to October 2015. This is a tertiary care Govt. Medical College Hospital located in the state headquarters i.e., Hyderabad of Telangana State, India.

\section{Aims and Objectives}

\section{Gender}

\begin{tabular}{|c|c|c|c|c|c|c|c|}
\hline \multirow{2}{*}{$\begin{array}{l}\text { Sl. } \\
\text { No. }\end{array}$} & \multirow{2}{*}{ Indicator/ Disease } & \multicolumn{2}{|c|}{ Male } & \multicolumn{2}{|c|}{ Female } & \multicolumn{2}{|c|}{ Total } \\
\hline & & No. & $\%$ & No. & $\%$ & No. & $\%$ \\
\hline 1 & Total No. of Cases who attended STD OPD (Denominator) & 1903 & 53.11 & 1680 & 46.89 & 3583 & 100 \\
\hline 2 & Total No. of Cases seropositives for either of 3 infections & 258 & 13.56 & 215 & 12.80 & 473 & 13.20 \\
\hline 3 & HSV-1 Positive & 124 & 6.52 & 116 & 6.90 & 240 & 6.70 \\
\hline 4 & HSV-2 Positive & 108 & 5.68 & 88 & 5.24 & 196 & 5.47 \\
\hline 5 & Both HSV-1 \& 2 Positive & 12 & 0.63 & 12 & 0.71 & 24 & 0.67 \\
\hline 6 & HSV Total Positive $(3+4-5)$ & 220 & 11.56 & 192 & 11.43 & 412 & 11.50 \\
\hline 7 & HBsAg Positive & 24 & 1.26 & 15 & 0.89 & 39 & 1.09 \\
\hline 8 & HCV Positive & 14 & 0.74 & 8 & 0.48 & 22 & 0.61 \\
\hline
\end{tabular}

To study seroprevalence of HBsAg, HSV \& anti-HCV antibodies in patients attending STD Clinic, Dept. Of DVL, Osmania Medical College/Osmania General Hospital, Hyderabad.

\section{MATERIALS AND METHODS}

It is a descriptive study (observational study) conducted between January 2015 - December 2015 at STD Clinic OPD, Dept. of DVL, Osmania General Hospital, Hyderabad. A total of 3,583 patients who attended the STD Clinic were studied and patients with direct or indirect risk factors were serotested for the 3 viral infections.

\section{Inclusion Criteria}

All patients in reproductive age group attending STD clinic with the direct and/or indirect sexual risk history and those who are willing for investigation under this study were included after taking informed consent.

\section{Exclusion Criteria}

Already known seropositives for HIV, Herpes, Hepatitis B, Hepatitis C, H/o HBV vaccine, H/o blood transfusion and patients not willing for study were excluded.

Following parameters are noted on entry into study: Detailed personal and sexual history of the patient and the spouse, cutaneous \& reproductive tract examination, blood investigations (ELISA is done for diagnosing Hepatitis B \& C and Herpes virus 1\&2) performed. The demographic details includes: Age, Gender, Literacy status, marital status, socioeconomic status.

\section{Procedure}

$5 \mathrm{~mL}$ of venous blood was aseptically drawn from antecubital vein of the participants into a plain bottle and was allowed to clot at room temperature; the blood was spun for 5 minutes at $2500 \mathrm{rpm}$ in a centrifuge to obtain serum. The serum obtained was tested for HBsAg, HCV antibodies, Herpes simplex virus $1 \& 2$ using Diaspot rapid diagnostic test strip and a third generation ELISA kit. The data obtained is calculated in percentage method.

\section{RESULTS} during the present study period from January 2015 to ctober 2015. A total of $473(13.20 \%)$ cases are found to be seropositives for either of 3 STIs with seroprevalence of $13.20 \%$ in which male seroprevalence is $13.56 \%$ (258 cases) female seroprevalence is $12.80 \%$ ( 215 cases). No single STD clinic attendee is positive for all 3 STIs.
A total number of 3,583 cases attended the STD Clinic OPD 
In the studied population of 3583, 412 cases were seropositives for HSV Antibodies with seroprevalence of $11.5 \%$, 39 were HBsAg Antibodies positive with seroprevalence of $1.09 \%$ and 22 cases were positive for HCV antibodies with seroprevalence of $0.61 \%$. The seropositivity in males and females respectively for HSV is $11.56 \%$ and $11.43 \%$; for $\mathrm{HBsAg}$ is $1.26 \%$ and $0.89 \%$; for $\mathrm{HCV}$ is $0.74 \%$ and $0.48 \%$.

\begin{tabular}{|c|c|c|c|c|c|c|}
\hline \multirow{2}{*}{ Sl. No. } & \multirow{2}{*}{ Indicator/Disease } & \multirow{2}{*}{ Total } & \multicolumn{2}{|c|}{ Male } & \multicolumn{2}{c|}{ Females } \\
\cline { 4 - 7 } & & & No. & $\mathbf{\%}$ & No. & \% \\
\hline 1 & Total no of Cases attended STD OPD & 3583 & 1903 & 53.11 & 1680 & 46.89 \\
\hline 2 & No. of seropositives for either of 3 infections & 473 & 258 & 54.55 & 215 & 45.45 \\
\hline 3 & HSV-1 Positive & 240 & 124 & 51.67 & 116 & 48.33 \\
\hline 4 & HSV-2 Positive & 196 & 108 & 55.10 & 88 & 44.90 \\
\hline 5 & Both HSV-1 \& HSV-2 Positive & 24 & 12 & 50.00 & 12 & 50.00 \\
\hline 6 & HSV Total Positive (3+4-5) & 412 & 220 & 53.40 & 192 & 46.60 \\
\hline 7 & HBSAg Positive & 39 & 24 & 61.54 & 15 & 38.46 \\
\hline 8 & HCV Positive & 22 & 63.64 & 8 & 36.36 \\
\hline \multicolumn{2}{|r|}{ Table 2. Gender Distribution among Seropositives } \\
\hline
\end{tabular}

Of the total 473 seropositives, the male positivity is 258 (54.55\%) and female positivity is 215 (45.45\%). All 3 STIs such as HSV, HBsAg and HCV have shown more prevalence in males than in females viz., 53.4:46.60, 61.54:38.46 and 63.64:36.36 respectively.

\begin{tabular}{|c|c|c|c|c|c|c|c|c|c|c|c|}
\hline \multirow{2}{*}{ STI } & \multirow{2}{*}{ Total } & \multicolumn{2}{|c|}{ 18-20 Years } & \multicolumn{2}{|c|}{ 21-30 Years } & \multicolumn{2}{|c|}{ 31-40 Years } & \multicolumn{2}{|c|}{ 41-50 Years } & \multicolumn{2}{|c|}{$>50$ Years } \\
\hline & & No. & $\%$ & No. & $\%$ & No. & $\%$ & No. & $\%$ & No. & $\%$ \\
\hline HSV-1 & 240 & 80 & 33.33 & 78 & 32.5 & 49 & 20.42 & 28 & 11.67 & 5 & 2.08 \\
\hline HSV-2 & 196 & 12 & 6.12 & 79 & 40.31 & 82 & 41.84 & 17 & 8.67 & 6 & 3.06 \\
\hline HSV-1 \& 2 & 24 & 0 & 0 & 3 & 12.5 & 9 & 37.5 & 7 & 29.17 & 5 & 20.83 \\
\hline Total HSV & 412 & 92 & 22.33 & 154 & 37.38 & 122 & 29.61 & 38 & 9.22 & 6 & 1.46 \\
\hline HbsAg & 39 & 0 & 0 & 22 & 56.41 & 7 & 17.95 & 7 & 17.95 & 3 & 7.69 \\
\hline $\mathrm{HCV}$ & 22 & 0 & 0 & 0 & 0 & 10 & 45.45 & 7 & 31.82 & 5 & 22.73 \\
\hline Total & 473 & 92 & 19.45 & 176 & 37.21 & 139 & 29.39 & 52 & 10.99 & 14 & 2.96 \\
\hline
\end{tabular}

In the present study, $92(19.45 \%)$ cases are below 20 years, 367 (77.58\%) cases are in between 21-50 years age. While no HBsAg and HCV are seen in early years of sexual activity (18-20 Years), all 3 STIs are seen in more than 31 years age group indicating that the longer the duration of sexual activity, higher the risk of acquiring asymptomatic STIs.

\begin{tabular}{|c|c|c|c|c|c|}
\hline \multirow{2}{*}{ STI } & \multirow{2}{*}{ Total } & \multicolumn{2}{|c|}{ Illiterate } & \multicolumn{2}{c|}{ Literate } \\
\cline { 3 - 6 } & & No. & $\mathbf{\%}$ & No. & \multicolumn{2}{c|}{ \% } \\
\hline HSV-1 & 240 & 164 & 68.33 & 50 & 25.51 \\
\hline HSV-2 & 196 & 146 & 74.49 & 6 & 25 \\
\hline HSV-1 \& & 24 & 18 & 75 & 120 & 29.13 \\
\hline Total HSV & 412 & 292 & 70.87 & 11 & 28.21 \\
\hline HBsAg & 39 & 28 & 71.79 & 4 & 18.18 \\
\hline HCV & 22 & 18 & 81.82 & $\mathbf{1 3 5}$ & $\mathbf{2 8 . 5 4}$ \\
\hline Total & $\mathbf{4 7 3}$ & $\mathbf{3 4 8}$ & $\mathbf{7 3 . 5 7}$ & \\
\hline
\end{tabular}

In the present study, literacy of the STD clinic attendees played a crucial role in transmission of STIs. The illiterates are more affected $(348 / 473=73.57 \%)$ when compared to the literates $(135 / 473=28.54 \%)$. The illiterates are at risk of participating in unprotected sex with the casual/regular partners, if the partner is asymptomatic at the time of sexual encounter, under the assumption that 'No genital lesions -No STIs'.

\begin{tabular}{|c|c|c|c|c|c|c|c|c|c|}
\hline \multirow{2}{*}{ STI } & \multirow{2}{*}{ Total } & \multicolumn{2}{|c|}{ Single } & \multicolumn{2}{c|}{ Married } & \multicolumn{2}{c|}{ Widow } & \multicolumn{2}{c|}{ Widower } \\
\cline { 3 - 10 } & & No. & $\mathbf{\%}$ & No. & $\mathbf{\%}$ & No. & \% & No. & \% \\
\hline HSV-1 & 240 & 50 & 20.83 & 183 & 76.25 & 7 & 2.92 & 0 & 0 \\
\hline HSV-2 & 196 & 31 & 15.82 & 154 & 78.57 & 11 & 5.61 & 0 & 0 \\
\hline HSV-1 \& 2 & 24 & 8 & 33.33 & 9 & 37.5 & 7 & 29.17 & 0 & 0 \\
\hline Total HSV & 412 & 73 & 17.72 & 328 & 79.61 & 11 & 2.67 & 0 & 0 \\
\hline HbsAg & 39 & 26 & 66.67 & 10 & 25.64 & 2 & 5.13 & 1 & 2.56 \\
\hline HCV & 22 & 0 & 0 & 17 & 77.27 & 4 & 18.18 & 1 & 4.55 \\
\hline Total & $\mathbf{4 7 3}$ & $\mathbf{9 9}$ & \multicolumn{8}{|c|}{ Table 5. Marital Status Among Positive Cases } & $\mathbf{3 5 5}$ & $\mathbf{7 5 . 0 5}$ & $\mathbf{1 7}$ & $\mathbf{3 . 5 9}$ & $\mathbf{2}$ & $\mathbf{0 . 4 2}$ \\
\hline \multicolumn{8}{|c|}{}
\end{tabular}


In the present study of 473 seropositives, 99 patients (20.93\%) are unmarried and the remaining 374 patients (79.07\%) are married and either living with the partner or widow (er). From the statistics, it appears the marriage is one influencing factor in transmission of infection to their regular partner, but the infected clients are failed to establish 'when and how' they got the infection i.e., pre or post-marital acquisition.

\section{Socioeconomic Status}

In the present study of 473 seropositives, 372 (78.65\%) are from lower socioeconomic group and 101 (21.35\%) are from middle socioeconomic group. The same higher prevalence is seen in lower socioeconomic group across all 3 infections.

There were zero cases from higher socioeconomic group. It can be attributed that the affluent society may be taking treatment for infections from private sector to avoid stigma of getting the services from Government Hospitals.

\section{Sexual Behaviour\& Practices}

In the present study of 473 seropositives, 386 (81.40\%) cases are heterosexuals (Males=171, 44.4\%; Females $=215,55.8 \%$ ) while $87(18.60 \%)$ cases being homosexuals. The same pattern is seen in across all 3 infections.

\begin{tabular}{|c|c|c|c|c|c|c|c|c|c|}
\hline \multirow{2}{*}{$\begin{array}{c}\text { Gender \& } \\
\text { Behaviour }\end{array}$} & \multirow{2}{*}{ Total } & \multicolumn{3}{|c|}{ Premarital Exposure } & \multicolumn{2}{c|}{ Confined to Marital Sex } & Extramarital Exposure & \multicolumn{2}{c|}{$\begin{array}{c}\text { Both Pre \& Extramarital } \\
\text { Exposures }\end{array}$} \\
\cline { 3 - 10 } & & No. & $\mathbf{\%}$ & No. & $\mathbf{\%}$ & No. & \% & No. & \% \\
\hline Men & 258 & 144 & 55.81 & 24 & 9.30 & 64 & 24.81 & 26 & 10.08 \\
\hline Women & 215 & 16 & 7.44 & 176 & 81.86 & 21 & 9.77 & 2 & 0.93 \\
\hline Total & $\mathbf{4 7 3}$ & $\mathbf{1 6 0}$ & $\mathbf{3 3 . 8 3}$ & $\mathbf{2 0 0}$ & $\mathbf{4 2 . 2 8}$ & $\mathbf{8 5}$ & $\mathbf{1 7 . 9 7}$ & $\mathbf{2 8}$ & $\mathbf{5 . 9 2}$ \\
\hline \multicolumn{8}{|c|}{ Table 6. Marital \& Extramarital Exposures } \\
\hline \multicolumn{8}{|c|}{}
\end{tabular}

It is observed that 176 of $215(81.86 \%)$ women are confined to marital sex while this behaviour is seen in 24 of 258 (9.30\%) men only. The 234 of 258 men are having either Premarital sex, Extramarital sex or combination accounting to $90.70 \%$, whereas this behaviour is seen in 39 of 215 $(18.13 \%)$ women only. It depicts that the women are more at risk of acquiring infection from the spouse. In 144 men with premarital exposures, $104(72.22 \%)$ are single and 40 (27.77) are married men. The longer the years of single status in men, more the risk of indulging in premarital sexual experimentation and higher risk of exposures.

\section{Condom Usage}

Though all men used condom at least once in their life, 100\% condom usage in all pre and extramarital encounters is not practised by any male participant. The usage of condom is influenced by availability of condom, personal and partner willingness, time and place of sexual activity and presence of visible genital lesions. In 215 women, 176 married women occasionally used condom to avoid pregnancy, as a hygienic measure during menstrual sex. 39 women with either of pre, extra and both also not used $100 \%$ condom in all sexual encounters. This study emphasises once again on importance of $100 \%$ condom usage in all sexual encounters.

\section{DISCUSSION}

The present study is conducted on 3583 STD Clinic attendees between January 2015 to December 2015. A total of 473 patients were found seropositives for either of 3 STIs with seroprevalence of $13.20 \%$. Various risk factors like Age, gender, literacy, socioeconomic studies, marital status and sexual behaviour were considered.

\section{Prevalence}

In the present study, prevalence of HSV positive cases was 11.5\% with HSV-1 6.7\% and HSV-2 5.5\%. These results were found to be comparable with $13 \%$ in Cusini $\mathrm{M}$ et al study group. ${ }^{7}$

Prevalence of HBsAg positive cases in the present study was $1.08 \%$. Prevalence of Anti-HCV antibodies positive cases in the present study was $0.61 \%$. This is comparable with
Tripathi PC et al, where in Seropositivity for HBsAg was $1.69 \%$ whereas HCV seropositivity was $0.4 \%$. A higher seroprevalence of HBsAg and HCV was found in males as compared with females. ${ }^{8}$

\section{Gender}

Overall in the present study, there is male preponderance.

Among HSV positive cases in the present study, male to female ratio was 1.14:1 with male predominance. These results were found to be consistent with that of 1.2:1 of V P Amudha et al study groups. ${ }^{9}$

Among HBsAg positive cases in the present study, male to female ratio was 1.7:1 with male predominance. These results were found to be comparable with that of 1.9:1 of Tripathi PC et al study. ${ }^{8}$

Among HCV positive cases in the present study, male to female ratio was 1.7:1 with male predominance. These results were found to be comparable with that of 2:1 of Antala. S.K et al study groups. ${ }^{10}$

\section{Age-wise Distribution}

Overall in the present study, most cases belonged to 21-30 yrs. and 31-40 yrs. age group.

Among HSV positive cases in the present study, the prevalence of $22.3 \%$ in $18-20$ yrs., $37.4 \%$ in $21-30$ yrs., $29.6 \%$ in $31-40$ yrs. and $10.7 \%$ in more than 41 yrs. were found to be comparable with that of J S Smith et al study prevalence of $14.3 \%, 45.2 \%, 28.5 \%$ and $12 \%$ respectively.

Among HBsAg positive cases in the present study, the prevalence of $56.4 \%$ in $21-30$ yrs., $17.9 \%$ in $31-40$ yrs. and $17.9 \%$ in more than $41-50$ yrs. and $7.8 \%$ in more than 50 yrs. were found to be comparable with that of Jafar et al with $56.5 \%, 19.6 \%, 17.4 \%$ and $6.5 \%$ respectively. ${ }^{11}$

Among HCV positive cases in the present study, the prevalence of $45.5 \%$ in $31-40$ yrs. and $31.8 \%$ in $41-50$ yrs. and $22.7 \%$ in more than $50 \mathrm{yrs}$. were found to be comparable with that of Jafar et al with 43\%, 30.7\%, 26.3\% respectively. ${ }^{11}$

\section{Literacy}

Among HSV positive cases in the present study, most of the cases were illiterates constituting $70.9 \%$ of total to the 
literates $29.10 \%$. These findings were found to be comparable with that of $72 \%: 28 \%$ of Chawla et al study groups. ${ }^{12}$

Among HBsAg positive cases in the present study, most of the cases were illiterates constituting $71.8 \%$. These findings were found to be comparable with that of $65.5 \%$ of Fawad Khan et al study groups. ${ }^{13}$

Among HCV positive cases in the present study, most of the cases were illiterates constituting $81.8 \%$ compared to literates $18.2 \%$. These findings were found to be comparable with that of $76.2 \%: 23.4 \%$ of Rajesh N Gacche et al ${ }^{14}$ and 72.4\%:27.6\% of A.N.Elzouki et al study group. ${ }^{15}$

\section{Marital Status}

Among HSV positive cases in the present study, most of the cases were married $79.6 \%$ constituting more than half, followed by single $17.7 \%$ (unmarried) and widow(er) $2.7 \%$. These findings were found to be consistent with that of $\mathrm{V} \mathrm{P}$ Amudha et al $^{9}$ study groups with $77.2 \%, 15 \%$ and $7.8 \%$ respectively.

Among HBsAg positive cases in the present study, most of the cases were singles with $66.7 \%$, followed by married with $25.6 \%$ and combination of widow(er) with $7.7 \%$. These findings were found to be consistent with Roshandel Gholamreza et al study with $69 \%$ and $31 \%$ respectively. ${ }^{16}$

Among HCV positive cases in the present study, most of the cases were married constituting $77.3 \%$, followed by widow(er) with $22.7 \%$. These findings were found to be consistent with Zamani $\mathrm{F}$ et al study with $76.8 \%$ and $20 \%$ respectively. ${ }^{17}$

\section{Socioeconomic Status}

Among HSV positive cases in the present study, the $78.6 \%$ are from lower socioeconomic status followed by $21.4 \%$ in middle socioeconomic status. These findings were found to be consistent with V P Amudha et al study group with $69 \%$ and $26 \% .^{9}$

Among HBsAg positive cases in the present study, 74.3\% cases were from lower socioeconomic status followed by $26.7 \%$ from middle socioeconomic status. These findings were found to be consistent with Fawad Khan et al study groups with $71 \%$ and $29 \%$ respectively. ${ }^{13}$

Among HCV positive cases in the present study, 86.3\% cases were from lower socioeconomic status followed by $13.7 \%$ in middle socioeconomic status. These findings were found to be consistent with Erin Gower et al study of $79 \%$ and $13.7 \%{ }^{18}$

\section{Sexual Behaviour}

Among HSV positive cases in the present study, most cases were heterosexuals, followed by homosexuals. These findings were found to be comparable with that of van de Laar MJ et al study group where in a strong independent association with the presence of HSV-2 antibodies was found for sexual behaviour, more specifically homosexual orientation, increasing number of years of sexual activity, increasing number of lifetime partners, number of past gonococcal infections, having receptive anal and (or) vaginal contact. ${ }^{19}$

Among HBsAg positive cases in the present study, most cases were heterosexuals, followed by homosexuals. These findings were found to be comparable with that of Ledy HS Oliveira et al study where in $95.4 \%$ related to have heterosexual life style and $3.6 \%$ were homo/bisexuals. However, $10.5 \%$ of the patients reported past homosexual relation. ${ }^{20}$

Among HCV positive cases in the present study, majority were heterosexuals. These findings were found to be comparable with that of M Rotily et al study groups. ${ }^{21}$ Our study shows inconsistent condom use is the main cause for transmission of these 3 viral STIs.

\section{Advantages of the Present Study}

1) The present study provides comprehensive estimation of HSV, HBsAg \& HCV prevalence in patients attending STD clinic in OMC \& OGH.

2) Proper counselling and early diagnosis and treatment will reduce complications/morbidity \& mortality and decrease fresh infections in the community.

3) Changes in sexual practices \& improved screening measures will reduce the risk of transmitted infections.

\section{Limitations of the Present Study}

1) Duration of the study is of short duration.

2) Prevalence of HBV, HCV \& HSV in patients attending STD clinic may not be a true reflection of total prevalence in the community. Broader studies are needed with large cohorts to estimate the prevalence of these infections in the community.

\section{CONCLUSION}

A total of 3,583 patients attending STD Clinic, Dept. of Dermatology, Venereology \& Leprology (DVL) were studied. A seroprevalence of $13.20 \%$ is seen for either of 3 STIs with male seroprevalence of $13.56 \%$ and female seroprevalence of $12.80 \%$. The seroprevalence for HSV, HBsAg and HCV is $11.5 \%, 1.09 \%$ and $0.61 \%$ respectively. The gender based seropositivity in males and females for HSV is $11.56 \%$ and $11.43 \%$; for $\mathrm{HBsAg}$ is $1.26 \%$ and $0.89 \%$; for $\mathrm{HCV}$ is $0.74 \%$ and $0.48 \%$ respectively. The illiterates (376 of $473=79.49 \%$ ) and people from Low socioeconomic status (371 of $473=78 \%$ ) are more affected. While 234 of 258 men are having either of Premarital, Extramarital or combination accounting to $90.70 \%, 176$ of 215 (81.86\%) women are confined to marital sex. It is observed that the risk of HSV, HBsAg \& HCV is increased with increasing sexual years and unprotected sex with multiple partners during pre and extramarital sex.

In this scenario, the awareness on STIs needs to be well informed before the start of the sexual activity by incorporating the STI/RTI education in school and college curriculum, through IEC activities like mass media campaigns, print \& electronic media, by using local cultural festivals, gatherings \& through marriage institutions. The at risk populations such as Sex workers, MSM \& IDUs should be covered through specific targeted interventions by utilising NGOs, local bodies and associations.

\section{REFERENCES}

[1] National AIDS control organisation, ministry of health \& family welfare, govt. of India. National RTI/STI technical guidelines 2014. http://naco.gov.in/sites/default/files/National\%20RT I\%20STI\%20technical\%20guidelines\%20Sep2014_1.

[2] Park SH, Rehermann B. Immune responses to HCV and other hepatitis viruses. Immunity 2014;40(1):13-24. 
[3] Chisari FV, Ferrari C. Hepatitis B virus immunopathogenesis. Annu Rev Immunol 1995;13:29-60.

[4] World Health Organization. Hepatitis B fact sheet no: 164 , 2017. http://www.who.int/mediacentre/factsheets/fs164/e n.

[5] Nowicki MJ, Laskus T, Nikolopoulou G, et al. Presence of hepatitis $\mathrm{C}$ virus (HCV) RNA in the genital tracts of HCV/HIV-1-coinfected women. J Infect Dis 2005;192(9):1557-65.

[6] Smith JS, Robinson NJ. Age-specific prevalence of infection with herpes simplex virus types 2 and 1: a global review. J Infect Dis 2002;186(Suppl 1):S3-28.

[7] Cusini M, Cusan M, Parolin C, et al. Seroprevalence of herpes simplex virus type 2 infection among attendees of a sexually transmitted disease clinic in Italy. Italian herpes forum. Sex Transm Dis 2000;27(5):292-5.

[8] Tripathi PC, Chakraverti TK, Khant NR. Seroprevalence of hepatitis B surface antigen and antibody to hepatitis $C$ virus at a tertiary care centre in Telangana. Int J Res Med Sci 2015;3(1):297-300.

[9] Amudha VP, Rashetha, Sucilathangam G, et al. Serological profile of HSV-2 in STD patients: evaluation of diagnostic utility of HSV-2 IgM and IgG detection. Journal of Clinical and Diagnostic Research 2014;8(12):DC16-9.

[10] Antala SK, Joshi TK. Seroprevalence of hepatitis B, hepatitis C and syphilis in HIV positive cases at ICTC, Rajkot. Gujarat Medical Journal 2010;65(1):23-6.

[11] Khan J, Shafiq M, Mushtaq S, et al. Seropositivity and coinfection of hepatitis B and C among patients seeking hospital care in Islamabad, Pakistan. BioMed Research International 2014;2014:4.

[12] Chawla R, Bhalla P, Bhalla K, et al. Community-based study on seroprevalence of herpes simplex virus type 2 infection in New Delhi. Indian J Med Microbiol 2008;26(1):34-9.
[13] Khan F, Shams S, Qureshi ID, et al. Hepatitis B virus infection among different sex and age groups in Pakistani Punjab. Virology Journal 2011;8:225.

[14] Gacche RN, Al-Mohani SK. Seroprevalence and risk factors for hepatitis c virus infection among general population in central region of Yemen. Hepatitis Research and Treatment 2012;2012:4.

[15] Elzouki AN, Smeo MN, Sammud M, et al. Prevalence of hepatitis $\mathrm{B}$ and $\mathrm{C}$ virus infections and their related risk factors in Libya: a national seroepidemiological survey East Mediterr Health J 2013;19(7):589-99.

[16] Gholamreza R, Shahryar S, Abbasali K, et al. Seroprevalence of hepatitis B virus and its co-infection with hepatitis D virus and hepatitis $C$ virus in Iranian adult population. Indian J Med Sci 2007;61(5):263-8.

[17] Zamani F, Sohrabi M, Poustchi H, et al. Prevalence and risk factors of hepatitis C virus infection in Amol city, north of Iran: a population-based study (2008-2011). Hepatitis Monthly 2013;13(12):e13313.

[18] Gower E, Estes C, Blach S, et al. Global epidemiology and genotype distribution of the hepatitis $\mathrm{C}$ virus infection. J Hepatol 2014;61(1 Suppl): S45-57.

[19] De Laar VMJ, Termorshuizen F, Slomka MJ, et al. Prevalence and correlates of herpes simplex virus type 2 infection: evaluation of behavioural risk factors. Int J Epidemiol 1998;27(1):127-34.

[20] Oliveira LH, Silva IR, Xavier BL, et al. Hepatitis B infection among patients attending a sexually transmitted diseases clinic in Rio de Janeiro, Brazil. Mem Inst Oswaldo Cruz 2001;96(5):635-40.

[21] Rotily M, Vernay-Vaisse C, Rousseau S, et al. Prevalence of HCV and HIV antibodies and related risk factors among entrants to the main southeastern French prison. Clinical Microbiology and Infection 1999;5(12):733-9. 